\title{
Byelorussian craftsmen in late seventeenth-century Russia and their influence on Muscovite architecture
}

\author{
BY
}

\section{LINDSEY A. J. HUGHES}

In the second half of the seventeenth century contacts between Muscovy and the Polish-occupied regions of Southern and Western Russia were greatly extended, both by the conscious efforts of the Muscovite government and ecclesiastical authorities to improve educational standards and as a result of the Union of Pereiaslavl and the subsequent Russo-Polish wars of 1654-67. The so-called Polish influence, noted by many scholars in the reigns of Aleksej Michajlovič and his successors, reached Russia for the most part via the Ukraine, Byelorussia and Lithuania. In the words of a historian of the period:

'This influence gradually manifested itself in both physical and psychological forms - on the one hand, in buildings, painting, clothing and music, on the other, in laws, customs, literature and language'. ${ }^{1}$

The strongly traditional art and architecture of Muscovy began to succumb to influences from neighbouring Slavic and Western European states. Elements of naturalism and baroque ornamentation appeared in icon-painting, whilst in architecture a modified order system was introduced. The haphazardly designed buildings of the mid-seventeenth century were replaced by symmetrically planned structures, lavishly embellished with motifs of Western European origin. Traditional Russian forms were fused with foreign decorative elements, culminating in the so-called Moscow Baroque style of the 1680 s-90s. ${ }^{2}$

Much attention has been paid to the role of Ukrainian influence in the development of Moscow Baroque. Indeed, the 'Ukrainian theory' has been adopted without question by a number of Western European scholars. The American art historian Arthur Voyce, for example, writes:

'Moscow received the motifs of the new style not in their pristine

1. I. A. Sljapkin, Sv. Dmitrij Rostovskij i ego vremja (1651-1709), St. Petersburg, 1891, p. 55.

2. On Moscow Baroque, see the following: F. F. Gornastajev, 'Barokko Moskvy', in I. E. Grabar', ed., Istorija russkogo iskusstva, II, Moscow, 1910, pp. 417-68; A. I. Nekrasov, ed., Barokko $v$ Rossii, Moscow, 1926; M. A. Il'in, 'Problema "moskovskogo barokko" XVII veka', Ježegodnik Instituta istorii iskusstv. 1956, Moscow, 1957, pp. 324-39; Il'in, 'Kamennoje zodčestvo konca XVII veka', in I. E. Grabar', ed., Istorija russkogo iskusstva, IV, Moscow, 1959, pp. 217-78 (this vol. henceforward IRI (1959)). 
form, directly from the West, but in a roundabout way, from the south, from the Ukraine, which in turn received them from Poland and Lithuania'. ${ }^{3}$

Less acknowledgement has been given to the role of Byelorussian craftsmen in introducing the Westernised decorative forms of the late seventeenth century. This is surprising in view of the large amount of documentation which exists to chart the activities of Byelorussian craftsmen in Muscovy, whereas any direct evidence of Ukrainian participation in the artistic field is remarkably scarce, despite certain similarities between Russian and Ukrainian architecture of the period. The exact nature of the Ukrainian contribution towards the architectural forms of late seventeenth-century Muscovy thus remains to be established; the role of the Byelorussians can be traced more precisely.

In the period 1654-67 large numbers of captives, fugitives and conscripts from the 'Polish towns' of Western Russia crossed the border into Muscovy, where many of them settled permanently. ${ }^{4} \mathrm{~A}$ register compiled by the Land Chancellery in 1658 shows that by that date there were already many Byelorussian traders and craftsmen - tailors, potters, butchers, bakers, cobblers, smiths - residing in Moscow. ${ }^{5}$ In 1672 a special area of the city, the Meščanskaja slobo$d a$, was set aside for the accommodation of Orthodox 'foreigners' from the Polish regions. ${ }^{6}$ The 1676 census of the settlement reveals that 412 of the 552 registered households were Byelorussian, a figure which did not include many of the specialists engaged on government service and lodged in other areas of the capital. ${ }^{7}$

Many records have survived of the recruitment of craftsmen from Byelorussian into Muscovite service. In 1656 and 1658 orders were given that

'craftsmen of various specialities be brought from the towns of Vilna, Połack, Viciebsk and Smolensk with their wives and children to work permanently in the Armoury (Oružejnaja palata) and that they be accommodated in tax-paying households in the Moscow Weapon-makers' settlement (Bronnaja sloboda). ${ }^{8}$

3. A. Voyce, The Art and Architecture of Medieval Russia, Norman, 1966, pp. 209-10. See also T. Talbot Rice, A Concise History of Russian Art, London, 1963, p. 134.

4. For general information, see L. S. Abecedarskij, Belorusy $v$ Moskve $v$ XVII veke, Minsk, 1957; Abecedarskij, ed., Russko-belorusskije svjazi. Sbornik dokumentov (1570-1667 gg.), Minsk, 1963 (henceforward RBS (1)); A. P. Ignatenko, ed., Russko-belorusskije svjazi vo vtoroj polovine XVII veka (1667-1687 gg.), Minsk, 1972 (henceforward RBS (2)).

5. RBS (1), no. 358.

6. See Polnoje sobranije zakonov Rossijskoj Imperii, I, St. Petersburg, 1830, p. 911.

7. 'Opis' moskovskoj meščanskoj slobody ..., Ctenija v Imp. Obščestve Istorii i Drevnostej Rossijskich, 1860, II.

8. Quoted in N. N. Sobolev, Russkaja narodnaja rez'ba po derevu, MoscowLeningrad, 1934, p. 74. The Moscow Armoury was established by Ivan IV for the production of small arms. By the mid-seventeenth century it had become a kind of Russian 'Academy of Arts', employing icon and portrait painters, carvers, coachbuilders etc. See V. Trutovskij, 'Bojarin i oružničij Bogdan Chitrovo i moskovskaja oružejnaja palata', Staryje Gody, JulySept., 1909, pp. 345 ff. 
In 1657 the tsar's agent P. Bolotnikov went to the towns of Smolensk, Barysaŭ, Minsk, Mahiloŭ and Vilna to hire craftsmen. ${ }^{9}$ In May 1660 the governor of Viciebsk wrote to the tsar about a request for the dispatch of various craftsmen to Moscow, complaining that there was a shortage of certain skilled men in the town. ${ }^{10}$ By 1660 there were about 79 qualified craftsmen and their pupils working in the Moscow Armoury from the towns of Połack, Viciebsk and Vilna alone, engaged as silversmiths, gunsmiths, carpenters, coachbuilders, locksmiths and carvers. ${ }^{11}$

Several projects on which Byelorussians were employed were of considerable significance for the further development of Russian architecture and applied art. In 1653, soon after his accession to the patriarchate, the ill-fated Nikon began to build a monastery on an island in lake Valdaj in the Novgorod region. ${ }^{12}$ The construction of the stone cathedral (1655-8) was supervised by Russian master mason Averkij Mokejev, but much of the decorative work - carved furnishing, iconostasis, doors, ceramics - was carried out by Byelorussian craftsinen. In 1654 a group of Byelorussians arrived at the island village of Bogorodicyna, ${ }^{13}$ followed in 1655 by monks from the Kucieina Monastery in Orša, who were accompanied by a contingent of Byelorussian tile-makers, carpenters and carvers. ${ }^{14}$ It was the latter who produced the iconostasis of the cathedral, carved in typically Byelorussian style, with high-relief decoration, intricately moulded naturalistic motifs and a frame based on the classical order system.

The remoteness of the Valdaj Iverskij Monastery from the capital naturally limited its influence upon craftsmen and patrons in Moscow. Far more influential was the design of Nikon's last and most grandiose project, the Monastery of the Resurrection at New Jerusalem (Istra), begun in $1656 .{ }^{15}$ The buildings were to bear the

9. $R B S(1)$, no. 358.

10. ibid., no. 400 .

11. ibid., no. 401 . See also nos. $381,386,393,402,443$. A. I. Uspenskij estimated that there were around 60 'foreigners' working in the Armoury in 1662 (Carskije ikonopiscy XVII veka, St. Petersburg, 1910, p. 24). According to $\mathrm{N}$. G. Veršinina there were 53 in 1665 ('Inozemcy i inozemnyje slobody $v$ MIoskve v XVII veke', Unpublished dissertation, Moscow, 1948, p. 36). Judging by the figures for 1660, most of these must have been Byelorussians See also J. Jodkowski, 'Artysci Polacy na dworze moskiewskim w XVII wieku'. Problemy, 1946, V; S. Biessonaŭ, 'Biełaruskija mastackija majstry ŭ Masívi.e XVII stahodździa' Vieści Akademii navuk BSSR. Seryja histariénaja, I, Minsk, 1947, pp. 75-81.

12. See Archimandrite Leonid, 'Akty Iverskogo svjatoozerskogo monastyrja', Russkaja Istoričeskaja Biblioteka, V, St. Petersburg, 1878; IRI (1959), pp. 168-72.

13. Abecedarskij, op. cit., p. 8.

14. Leonid, 'Akty', no. 48, p. 9, 14. Sobolev, op. cit., p. 79; Abecedarskij, op. cit., pp. 9-10.

15. See Archimandrite Lconid, Istoričeskoje opisanije stavropigial'nogo Voskresenskogo Novyj Ierusalim imenujemogo monastyrja, Moscow, 1876; A. I. Nekrasov, 'Architektura Istry i eje značenije $\mathrm{v}$ obščem razvitii russkogo zodčestva', Ježegodnik Muzeja architektury, I, Moscow, 1937, pp. 9-51; A. V. Sčusev, Projekt vosstanovlenija goroda Istry, Moscow, 1946; G. B. Alferova, ' $\mathrm{K}$ voprosu o stroitel'noj dejatel'nosti Patriarcha Nikona', in Architekturnoje nasledstvo, XVIII, Moscow, 1969, pp. 30-44. The monastery was mined by the Germans in World War II and is at present being restored. 


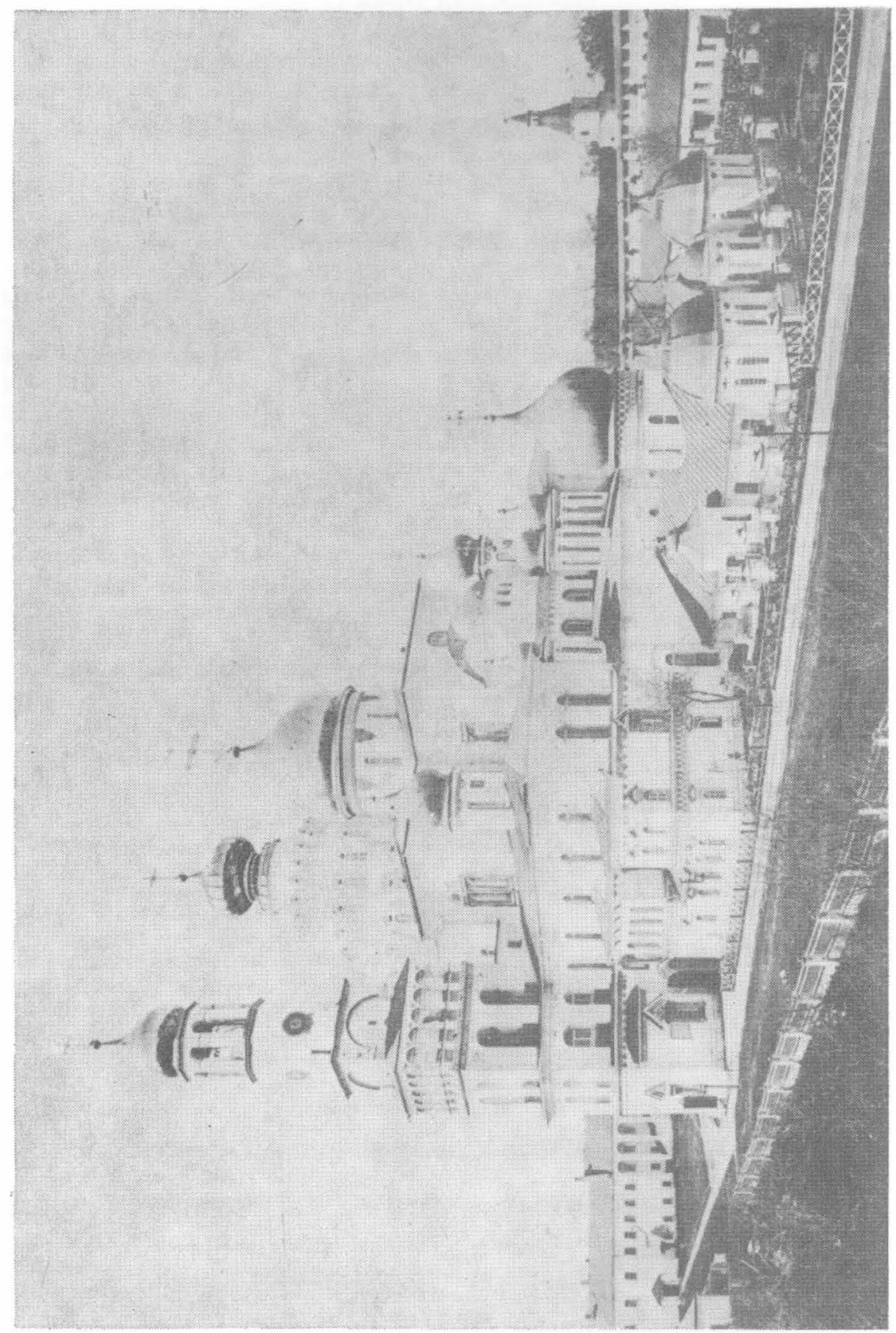

Monastery of the Resurrection at New Jerusalem, 1656-85. (Ščusev Museum of Architecture, Moscow) 
names of the Holy Places in Jerusalem and the cathedral was to be modelled on the Church of the Holy Sepulchure. (See Illustration 1.).

Once again Nikon made use of Byelorussian craftsmen, some of whom were transferred from Valdaj after the completion of work there. A document of 1658 refers to the dispatch of 32 Byelorussian families to the vicinity of Istra. ${ }^{16}$ In 1665 the Dutchman Nicolaas Witsen, later major of Amsterdam, remarked upon the presence of 'Polish' workers in the monastery, ${ }^{17}$ as did the compiler of Patriarch Nikon's Life. ${ }^{18}$

More specific details of the origin and specialities of these craftsmen are supplied by a document of December 1666. In that year building was halted as a result of Nikon's fall from favour and a royal decree was issued ordering a register to be made of 'foreigners (ljudej inozemcev) employed now or formerly in the Monastery of the Resurrection as gold- and silversmiths, carvers and in other capacities'. ${ }^{19}$

Shortly afterwards 31 craftsmen, both Russians and 'foreigners', were transferred from Istra to Moscow, where they were for the most part conscripted into either the Armoury or the Chancellery of the Royal Household (prikaz Bol'šogo Dvorca). The register provides biographical details of 17 craftsmen from Byelorussia three gunsmiths, six carpenters/carvers, five tile-makers, two glaziers and a powder maker. ${ }^{20}$

The authors of an article in the multi-volumed Istorija russkogo iskusstva suggest that other Byelorussian craftsmen, unrecorded in the 1666 register, may have worked for Nikon, namely Petr Ivanovič Zaborskij and the monks Arsenij and Ippolit. ${ }^{21}$ Zaborskij's absence from the list is explained by the fact that he died in 1665. According to Archimandrite Leonid, author of a detailed history of the monastery at New Jerusalem, he was hired by Nikon 'from across the Lithuanian border' in 1658, to direct tile-making operations in

16. Leonid, Istoričeskoje opisanije, p. 11.

17. A. M. Lovjagin, 'Nikolaj Vitsen iz Amsterdama u Patriarcha Nikona', Istoričeskij vestnik, Sept. 1899 , p. 877.

18. N. K. Sušerin, Zitije svjatejšgo Patriarcha Nikona, St. Petersburg, 1784, p. 75.

19. Sobolev, op. cit., p. 79.

20. Leonid, Istoričeskoje opisanije, pp. 759-65. The names were as follows: gunsmiths - Maksim Michailov, Trofim and Andrey Terlik all from Kopyś; carpenters/carvers - Klim Michajlov from Škłoŭ, Andrej Fedorov from Orša, Gerasim Okulov from Dubroŭna, Osip Andrejev from Vilna, Jakov Ivanov from Viciebsk and pupil Fedor Mikulajev from Dubrounna; tilemakers - Ignat Maksimov from Kopyś, Stepan Ivanov (Polubes) from Mścisłaŭ, Samoška Grigor'jev from Kopyś and pupils Osip Ivanov from Škłoŭ and Fedor Ciuka from Vilna; glaziers - Ivan Volčkov from Ašmiany and pupil Zinovej Dmitrijev from Veliž; powder maker - Ivan Ostaf'jev from Smolensk.

21. N. E. Mneva, N. N. Pomerancev, M. M. Postnikova- Loseva, 'Rez'ba i skul'ptura XVII veka', in IRI (1959), pp. 306-8. The artist Karp Zolotarev is also mentioned, but there is no evidence that he was Byelorussian. See Z. E. Kališevič, 'Chudožestvennaja masterskaja Posol'skogo Prikaza v XVII veke i rol' zolotopiscev v eje sozdanii i dejatel'nosti', in N. V. Ustjugov, ed., Russkoje gosudarstvo $v$ XVII veke, Moscow, 1961, pp. 392-411. 
the monastery..$^{22} \mathrm{His}$ gravestone survives, with an inscription, allegedly written by Nikon himself, enumerating Zaborskij's many skills. It seems doubtful whether either Arsenij or Ippolit worked for Nikon. N. N. Sobolev records that they were already working for the tsar in Moscow in $1666^{23}$ but Ippolit may have been engaged at Istra during the completion of the buildings in 1679-86. ${ }^{24}$

The most striking contribution of the Byelorussian craftsmen were the glazed ceramic tiles which decorated the exterior and interior of the Cathedral of the Resurrection. ${ }^{25}$ Not only did they produce simple rectangular tiles for friezes around walls and under domes, but they also constructed window-surrounds, portals and iconostases of multicoloured ceramic. The designs were based on the classical order system, which was later to be employed extensively in the stone decoration of Moscow Baroque architecture. The practice of decorating buildings with tiled friezes was also to be popularised by the Byelorussians in the $1660 \mathrm{~s}-70 \mathrm{~s}$. Leonid reports that in the 1870 s tilemaking was still a flourishing concern in the Istra district. ${ }^{26}$

No doubt much interesting wood-carving work was also produced at New Jerusalem but little appears to have survived. The Byelorussian carvers were to gain fame for their later work in and around Moscow, of which more will be said below.

The influence of the Monastery of the Resurrection on the further development of Muscovite architecture has been noted by many scholars. The leading Soviet architectural historian M. A. Il'in, for example, writes that:

'Many of the forms of the exterior ornamentation not only anticipated but also served as models for the exponents of the subsequent Moscow Baroque.'27

The monastery was much frequented by members of the Muscovite royal family. It was tsar Fedor who, after a visit there in 1679, provided the funds for its completion. ${ }^{28}$ Tsarevna Sofija Aleksejevna, one of the chief patrons of the new Europeanised architecture of the 1680 s, was a regular visitor and was present, with other relatives, at the consecration of the cathedral in January $1685 . .^{29}$ In the same year Prince Vasilij Golicyn, himself an enthusiastic patron of architecture, ordered detailed sketches of the buildings and had a wooden model brought to Moscow. ${ }^{30}$ There is also evidence that he used Byelorussian tile designs in the building of his own palace in Moscow. ${ }^{31}$ Thus

22. Archimandrite Leonid, 'Cenninoje delo v Voskresenskom Novyj Ierusalim imenujemon monastyre', Vestnik obščestva drevnerusskogo iskusstva pri moskovskom publičnom muzeje, 1876, nos. 11-12, p. 82.

23. Sobolev, op. cit., p. 80.

24. A. I. Leonov, ed., Russkoje dekorativnoje iskusstvo, I, Moscow, 1962, p. 287. See also $R B S(2)$, nos. 206, 209.

25. See Leonid, 'Cenninoje delo', p. 83; A. Fillipov, Izrazcovyj naličnik $v$ Novom lerusalime $i$ ego otmyvka, Moscow, 1917.

26. Leonid, 'Cenninoje delo', p. 84.

27. M. A. Il'in, Podmoskov'je, Moscow, 1965, p. 216.

28. S. M. Solov'jev, Istorija Rossii s drevnejšich vremen, XIII, Moscow, 1962 p. 258.

29. Leonid, Istoričeskoje opisanije, p. 144.

30. ibid., pp. 69-70.

31. Abecedarskij, op. cit., p. 40. 
leading figures of the time were familiar with the work of the Byelorussians, whose skills were fully utilised in court projects after their removal to Moscow in 1666.

One of the most successful was Klim Michajlov from Skłoŭ. He came to Moscow in the service of Prince Grigory Kurakin in 1654 and in 1655 went to work for Patriarch Nikon. ${ }^{32}$ According to the 1666 register, he worked at Istra for eight years as a carpenter and wood-carver (...delajet reznoje delo po derevu pod zolotom, da stoljarnoje delo). ${ }^{33}$ In 1667-8 he worked with a band of Byelorussian craftsmen, including David Pavlov, Andrej Ivanov, Gerasim Okulov and Fedor Mikulajev, on the construction of the tsar's wooden palace at Kolomenskoje. ${ }^{34}$ Under the direction of the monk Arsenij from Orša, they prepared decorative carvings for the interior and exterior of the fanciful building. (See Illustration 2.)

In 1670-1 Michajlov and his Byelorussian colleagues Pavlov, Okulov and Ivanov carved a wooden shrine for the relics of St. Savva the Miracle-Worker. ${ }^{\text {s5 }}$

The rewards of service were evidently variable. In 1675 Michajlov and five assistants complained to the tsar that they had received no provisions for six months and were 'dying of hunger'.36 In August 1679 , however, Michajlov and 35 assistants received a money payment in place of the usual grant of provisions for constructing an iconostasis for the Cathedral of the Intercession at Izmajlovo ${ }^{37}$ and later the same year Michailov was rewarded with five altyns of crimson cloth ' $z a$ mnoguju ego rabotu'.38

In 1680 Michajlov was at the Aleksandrovskaja Sloboda 'on the sovereign's business' ${ }^{39}$ and in 1684 participated in the making of a large wooden cupboard for tsarevna Jekaterina Aleksejevna. ${ }^{40}$ Byelorussian craftsmen were encouraged to train Russian pupils; a report of 1679 noted with approval that certain apprentices modelled their work upon that of Klim Michajlov and Gerasim Okulov. ${ }^{41}$

After the death of Arsenij in 1681, Michajlov took over as head of the 'carving and joinery' section of the Moscow Armoury. Under his direction the workshop produced a number of iconostases for royal churches in and around the capital. The biggest project was the iconostasis for the old Cathedral of Our Lady of Smolensk in the Novodevičij Convent, commissioned by Sofija Aleksejevna in $1683 .^{\mathbf{4 2}}$

32. Leonid, Istoričeskoje opisanije, p. 762. See also Sobolev, op. cit., pp. 80 ff.; Abeccdarskij, op. cit., pp. 32-3; M. P. Capenko, cd., Zodčestvo Ukrainy, Kiev, 1954, pp. 264 ff; Ju. Ovsjannikov, Novodevičij monastyr', Moscow, 1968 , p. 139.

33. Leonid, Istoričeskoje opisanije, p. 762.

34. On the construction of the palace, see documents in I. Zabelin, Domasnij byt russkich carej $v$ XVI $i$ XVII stoletijach, 3nd ed., Moscow, 1895, pp. 444-81. See also IRI (1959), pp. 95-7, 309-10.

35. RBS (2), nos. 46,65 .

36. ibid., no. 119 .

37. ibid., no. 192 .

38. ibid., no. 202.

39. ibid., no. 210.

40. ibid., no. 246.

41. Sobolev, op. cit., pp. 78-9, note 4.

42. ibid., pp. $173 \mathrm{ff}$; Abecedarskij, op cit., pp. 32-3; IRI (1959), p. 316; RBS (2), no. 234. 


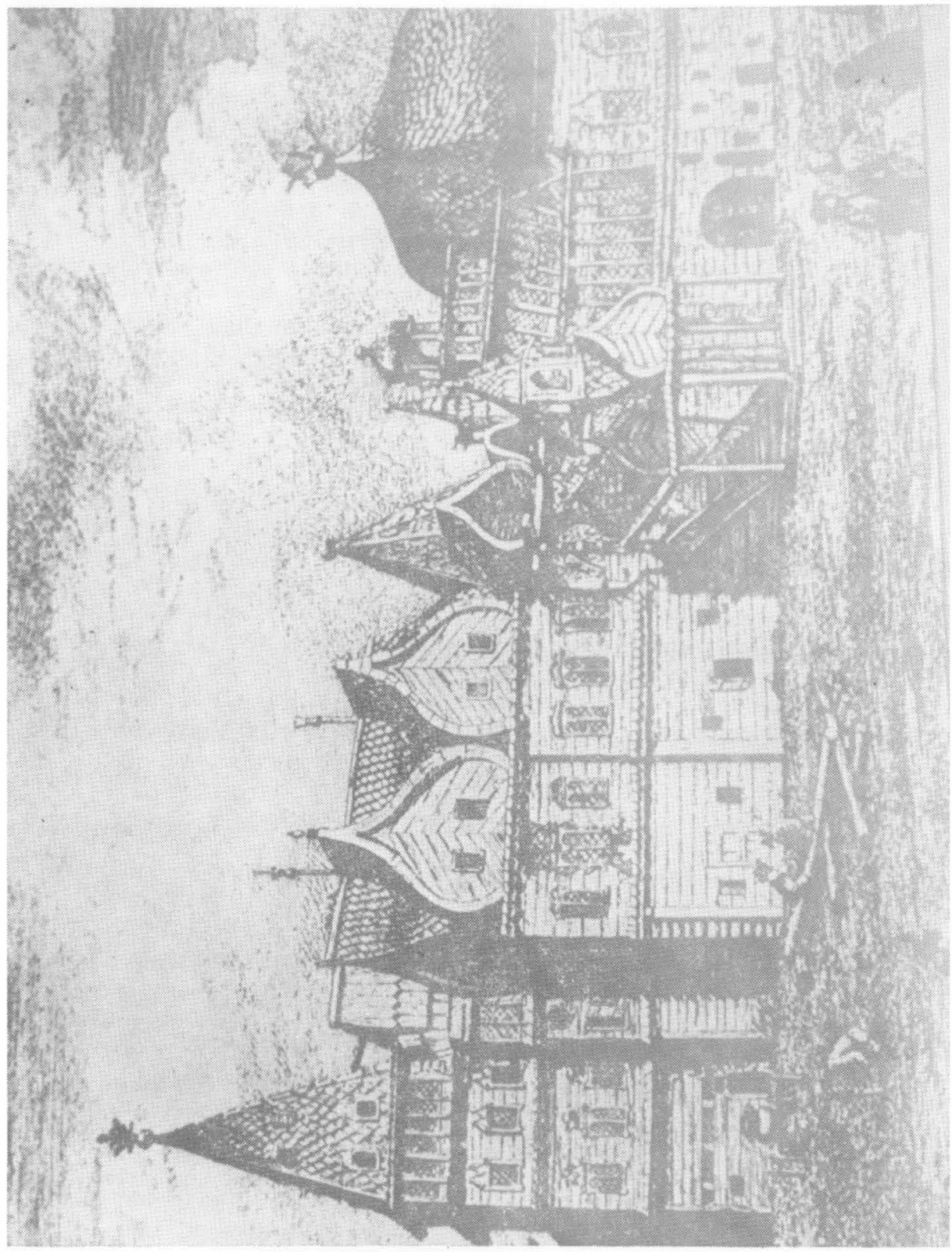

Wooden palace at Kolomenskoje, 1667-81. (XVIIIth century engraving) 
Michajlov and 25 assistants finished the job in $1685 .{ }^{43}$ The making of the huge iconostasis occupied so many qualified workmen that in January 1685 some of the pupils of Byelorussian master Osip Andrejev were hired to build choir screens for the cathedral. Klim Michajlov assured the palace authorities that the apprentices would make the screens 'with frames and columns and carved capitals of highquality workmanship'. ${ }^{44}$ The carving work in the Novodevičij Convent, which has survived to the present day, provides a striking testimonial to the skill of the Byelorussians. (See Illustration 3.)

Throughout the period Byelorussians were associated with the production of iconostases for new churches in the Moscow Baroque style. In 1679 Michajlov supervised the construction of the iconostasis of the Cathedral of the Intercession at Izmajlovo ${ }^{45}$ and in 1689, together with Gerasim Okulov and Stepan Zinov'jev, made another for the nearby Church of Prince Josaphat, reconstructed by Sofija Aleksejevna in the Moscow Baroque style in 1688.46 In 1686 Okulov made an iconostasis for the Church of SS. Peter and Paul in the Moscow Kremlin. ${ }^{47}$ Byelorussians also worked on the iconostasis for the 'new' cathedral of the Donskoj Monastery. ${ }^{48}$

As has already been noted, these Byelorussian iconostases were remarkable for the incorporation of the classical order system into their design; icons were framed by carved columns with bases and capitals and by profiled cornices. The carving was in high relief, in sharp contrast to the flat tracery of earlier Russian work, in a style described by N. N. Sobolev as 'Polish-German baroque'. ${ }^{49}$

It is worth noting that Byelorussian carvers made use of pattern books in the course of their work. In 1668 two illustrated manuals on carving (dve knigi masterskije $k$ reznomu delu $v$ licach) were taken from New Jerusalem by Klim Michajlov, no doubt for use at Kolomenskoje. ${ }^{50}$ Sobolev suggests that the Byelorussians derived many of their designs from this source and may even have had some influence in popularising the practice amongst Russian craftsmen, who in the $1680 \mathrm{~s}-90 \mathrm{~s}$ began to make regular use of foreign architectural manuals and engravings. ${ }^{51}$

The tile-makers (cenninich del mastera) from Istra were also employed at court. In 1668-72 Ignat Maksimov from Kopyś (who had worked at both Valdaj and Istra) and Stepan Ivanov Polubes from Mścisłaŭ prepared tiled friezes for the Church of St. Gregory of New

43. IRI (1959), p. 316.

44. $R B S(2)$, no. 249.

45. ibid., no. 192.

46. Dopolnenija k aktam istoričeskim, XII, no. 58; Abecedarskij, op cit., pp. 33-4.

47. $R B S(2)$, no. 270 .

48. I. Zabelin, Istoričeskoje opisanije moskovskogo stavropigial'nogo Donskogo monastyrja, Moscow 1865, pp. 149-55.

49. Sobolev, op. cit., p. 82.

50. ibid., pp. 95-6 See also RBS (1), no, 464, note from the Superior of the Monastery at New Jerusalem to the Armoury (Jan. 1667) on the dispatch of tools and a craftsman's manual, also no. 465.

51. Sobolev, op. cit., p. $94,157$. 


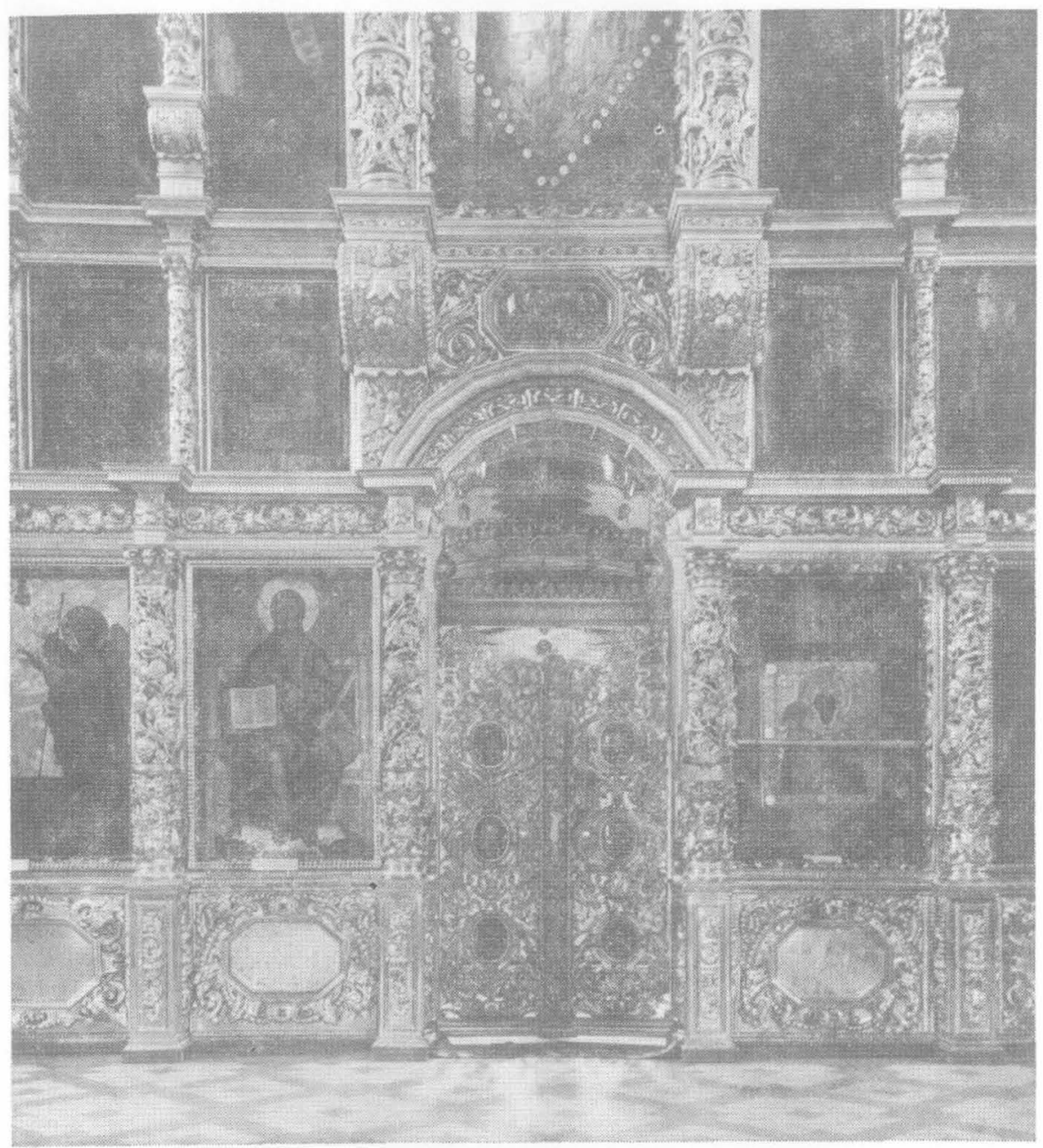

Cathedral of Our Lady of Smolensk, Novodevichy Convent, iconostasis 1683-5. (Ščusev Museum of Architecture, Moscow) 
Caesaria, built for the tsar's confessor.52 They also made tiles for the drums and arched bays of the Cathedral of the Intercession at Izmajlovo in $1671-4 .^{53}$ There is also evidence to suggest that these and other craftsmen made tiles for buildings in Jaroslavl' and in the Joseph of Volokolamsk Monastery. ${ }^{54}$ The tiled decoration of the famous Krutickij Teremok in Moscow (1692-3) has been attributed to the Russian architect Osip Starcev ${ }^{55}$ but Starcev himself was evidently strongly influenced by Byelorussian designs. In 1681 he had made tiles for the cornice and domes of the renovated Upper Church of the Saviour in the Kremlin, using designs made by the monk Ippolit. ${ }^{56}$ (See Illustration 4.).

Apart from the documented cases referred to above, the hand of Byelorussian craftsmen has been suspected in other monuments of the period. The Russian art historian M. Krasovskij, for example, suggested that the ornate circular Church of the Sign at Dubrovicy near Moscow (1690-1704) may have been designed by 'a Pole who studied in Italy and then came to Moscow amongst those carvers recruited in to the Armoury under Aleksej Michajlovič and Bogdan Chitrovo'.5 There seems to be no documentary evidence for this theory.

L. S. Abecedarskij put forward the theory that Jakov Grigor'jevic Buchvostov, one of the best known architects of the Moscow Baroque era, may have been of Byelorussian origin. ${ }^{58}$ Abecedarskij points out that Buchvostov was often referred to as 'Janka' in documents. Moreover, he cites an inscription from the death register of the Church of the Trinity at Troickoje-Lykovo (c. 1698-1704), commemorating 'stone-masons Michail and Mitrofan and Jakov, their master and other foreigners (inyje inozemnii) who built and decorated this Thy Church'.59

M. A. Il'in attributes the authorship of the Church of the Trinity to Buchvostov on the basis of this inscription. ${ }^{60}$ However, although he suggests that the 'foreigners' may have been Byelorussian carvers, he nowhere implies that Buchvostov himself was Byelorussian. In fact, the authenticity of the lost inscription has been disputed, for example by architectural historian P. A. Tel'tevskij, who argued that its vocabulary was of a much later date. ${ }^{61}$ In no known documents is

52. Leonid, 'Cenninoje delo', p. 83; Leonid, Istoričeskoje opisanije, p. 793; Russkaja istoričeskaja biblioteka, XXIII, pp. 831-2. On Polubes, see Russkoje dekorativnoje iskusstvo, pp. 285-7.

53. Vremennik Imp. Obščestva Istorii i Drevnostej Rossijskich, XXIV, 1856, p. 37.

54. See Abecedanskij, op cit. p. 38; Il'in, Podmoskov'je, p. 244.

55. N. Soł̌ina, 'Krutickij teremok v Moskve', Architekturnoje nasledstvo, VI, Moscow, 1956, pp. 136-7.

56. Zabelin,, Domašnij byt, p. 594.

57. M. V. Krasovskij, 'Cerkov' sela Dubrovic', in Izvestija Imp. Archeologičeskoj Kommissii, XXXIV, 1910, pp. 60-1.

58. Abecedarskij, op cit., pp. 50-1.

59. Cited in V. N. Ivanov, P. N. Maksimov, S. A. Toropov, Sokroviša russkoj architektury, Moscow, 1950, p. 239.

60. M. A. Il'in, Zodčij Jakov Buchvostov, Moscow, 1959, p. 111.

61. P. A. Tel'tevskij, Zodčij Buchvostov, Moscow, 1960, p. 78. 


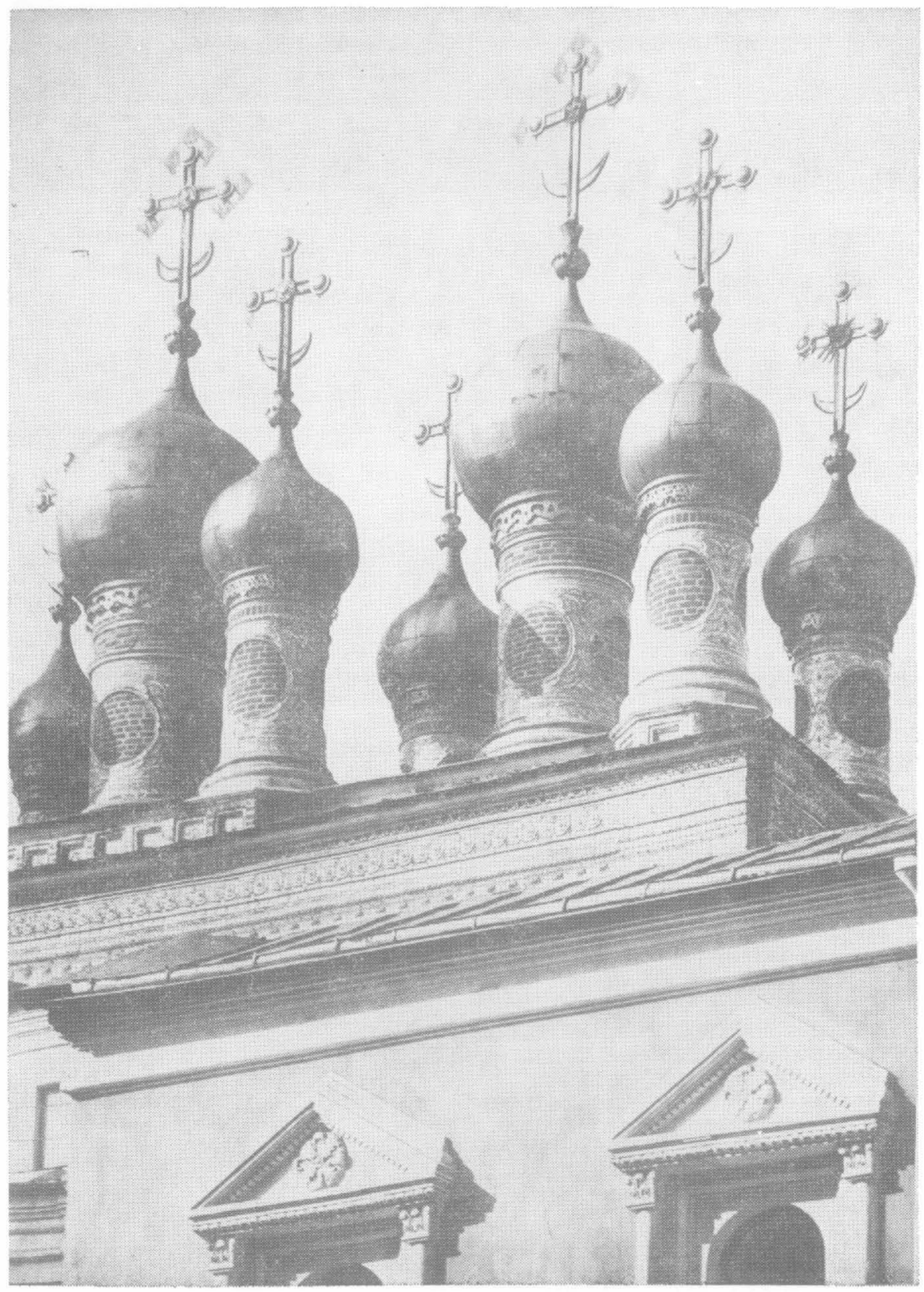

Upper Church of the Saviour, Kremlin. Tiled drums and frieze, 1681. 
Buchvostov, a serf from the estate of M. Ju. Tatiščev in the Dmitrov region, referred to as a 'foreigner'. ${ }^{62}$

The presence of Byelorussian architects or masons in late seventeenth-century Muscovy has yet to be established. The evidence at present available shows that, in the architectural field, Byelorussians were concerned with the preparation of decorative components for the exterior and interior of buildings and it is within these limits that their influence must be assessed.

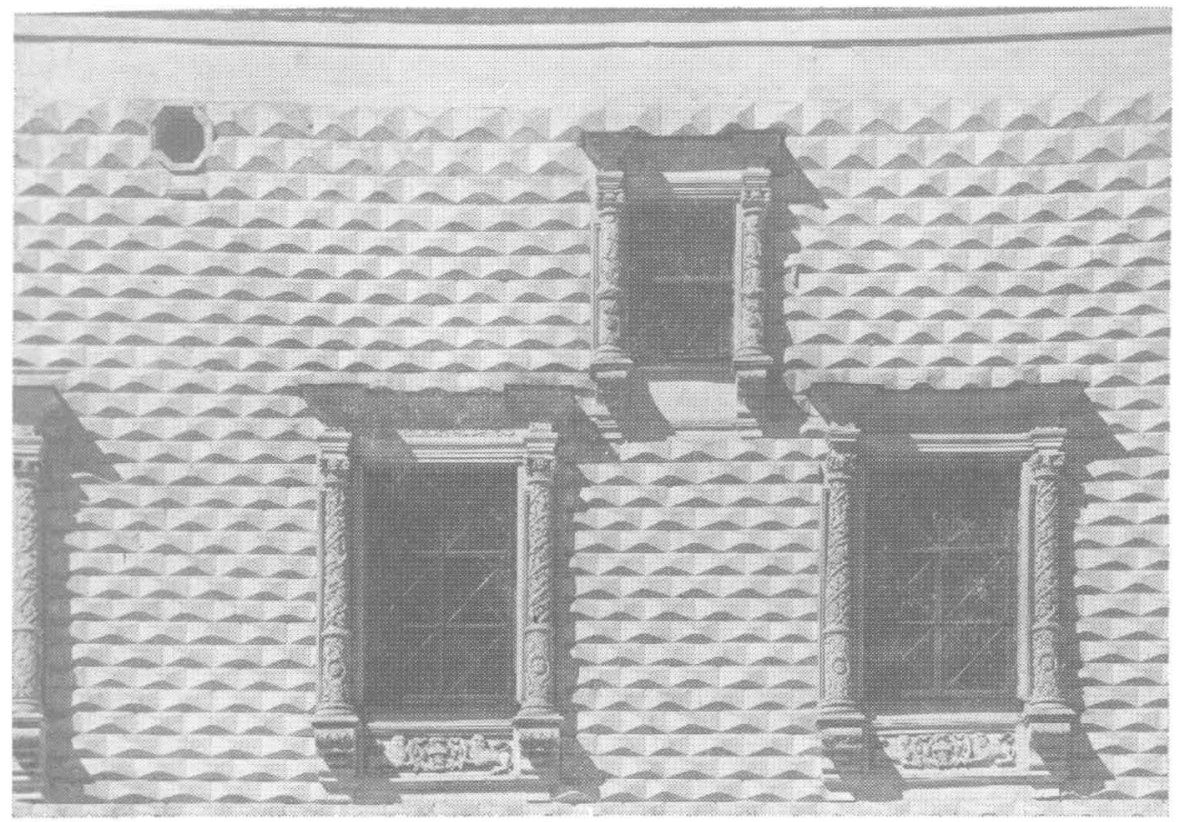

Kremlin Palace of Facets, Window surrounds, c. 1684. (Ščusev Museum of Architecture, Moscow)

Their main contribution was in the introduction of elements of the Western European order system. Although snatches and fragments of Renaissance architecture reached Muscovy before the $1680 \mathrm{~s}$, it was not until the latter part of the seventeenth century that Western proportions and details were extensively applied to Muscovite buildings, producing the short-lived Moscow Baroque. M. A. Il'in attributes this new direction to the influence of Byelorussian craftsmen ${ }^{63}$ whilst I. E. Grabar' spoke of the 'iconostasation' (obikonostasen'je) of Russian architecture during the period. ${ }^{64}$ To take but one example, the

62. See documents in Il'in, Zodčij, pp. 176, 179, 180 et al.

63. See Il'in, 'Problema', pp. 332-4; Il'in, Zodčij, pp. 19-20; Il'in, 'Svjazi russkogo, ukrainskogo, i belorusskogo iskusstva vo vtoroj polovine XVII veka', Vestnik Moskovskogo Gos. Universiteta. Serija obščestvennych nauk, VII, 1954, pp. 75-84; Il'in, Kamennaja letopis' moskovstoj Rusi, Moscow, 1966, p. 273.

64. I. E. Grabar', Russkaja architektura pervoj poloviny XVIII veka, Moscow, 1954 , p. 39. 
window surrounds of the renovated Palace of Facets, (c. 1684) bear a striking resemblance to the wooden frames of iconostases carved in the Byelorussian style. (See Illustration 5.).

A further indication of the innovatory role of Byelorussian craftsmen is to be found in the vocabulary of documents of the period. In contracts, lists and wages records connected with the production of iconostases the technical jargon of the classical order system makes its appearance in Russia. A list of components for the iconostasis of the Church of Prince Josaphat at Izmajlovo (1689) included ten capitals (kaptelej) and a carved cornice (karniz). ${ }^{65}$ The iconostasis of the Church of the Intercession in the Novodevichy Convent, made in the same year, had carved corbels (karanštiny), capitals and bases (bazy). ${ }^{66}$ As mentioned earlier, Klim Michajlov spoke of the 'carved capitals' of the Smolensk Cathedral choir screens. ${ }^{67}$ A closer examination of the comparative dates of the appearance of the vocabulary of classical architecture in Byelorussia and Muscovy would doubtless be of interest.

Apart from the many Byelorussians who visited and settled in Muscovy, certain Russians also had the opportunity of observing life in the 'Polish towns' of Byelorussia. Dr. Samuel Collins, the royal physician, wrote of Aleksej Michajlovič:

'Since His Majesty has been in Poland and seen the manner of the Princes' houses there and ghess'd at the mode of their Kings, his thoughts are advanced and he begins to model his court and edifices more stately, to furnish his rooms with tapestry and contrive houses of pleasure abroad.'68

The tsar's letters from the campaign of 1654-6 reveal that he visited many towns in the western area, including Smolensk, Połack, Viciebsk and Vilna. ${ }^{69}$ This was no pleasure trip but, as Collins suggests, Aleksej was impressed by the life-style of the gentry. One of the 'houses of pleasure' which he later built was the wooden palace at Kolomenskoje, decorated with carvings by Byelorussian craftsmen and with wall-paintings by the artist Stanislas Lopuckij from Smolensk. ${ }^{70}$ As mentioned earlier, Byelorussians were also employed at the royal estate of Izmajlovo, which was set up as a horticultural centre during Aleksej's reign.

Russian stone-masons also visited Byelorussia. In 1674 Ivan Kalinik went to Smolensk, restored to Muscovy in 1667, to inspect the old Cathedral of the Assumption.71 In 1677 tsar Fedor sent Aleksej

65. Dopolnenija $k$ aktam istoričeskim, XII, no. 58.

66. Zabelin, Domašnij byt, p. 616. See ibid., p. 615 for a similar description of an iconostasis in a chapel of the Novodevičij cathedral.

67. RBS (2), no. 249.

68. Collins, The Present State of Russsia. In a letter to a friend at London, London, 1671, pp. 64-5.

69. Pis'ma russkich gosudarey $i$ drugich osob carskogo semejstva, V, Pis'ma Alekseja Michajlovica, Moscow, 1896.

70. Lopuckij entered the Armoury in 1655. See Uspenskij, Carskije ikonopiscy, II, p. 160; Zabelin, Domašnij byt, p. 214.

71. S. A. Sirjajev, 'Pamjatniki barokko i vlijanije zodčestva Moskvy v architekture Smolenska XVII i XVIII veka', Trudy Smolenskich gosudarstvennych muzejev, I, Smolensk, 1924, p. 14. 
Korolkov to the city to supervise the reconstruction of the cathedral. ${ }^{72}$ In 1692 master mason Gur Vachromejev began to build a cathedral in the Monastery of the Ascension in Smolensk ${ }^{73}$ and was joined for a short period in 1693 by court architect Osip Starcev. ${ }^{74}$

Thus diffusion was a two-way process. In the newly conquered or occupied regions monuments were erected or renovated in the Muscovite style. The influence of the Byelorussians within the Muscovite state was more varied and subtle. The craftsmen from the 'Polish towns' introduced their native designs in carving, tile-making and other applied arts, bringing with them elements of Polish Renaissance and Baroque art. This in turn was reflected in the forms of Moscow Baroque architecture. This is not to suggest that other influences were not also at work. The possible role of the Ukraine has been mentioned. There was also a steady influx of technical specialists from the 'German states' from the reign of Michail Fedorovič onwards, not to mention the many foreign books, often profusely illustrated with architectural motifs, which found their way into Muscovite libraries during the seventeenth century.

The heightened receptiveness to foreign culture which arose amongst certain members of the Muscovite nobility and the everwidening opportunities for acquiring knowledge of that culture could not but eventually be reflected in art and architecture. Byelorussian craftsmen played a significant role in this 'Westernising' process and their influence provides at least part of the answer to the problem of the origins of Moscow Baroque.

72. ibid.

73. ibid., p. 17.

74. V. P. Vygolov, Tvoř̌estvo zodčego O. D. Starceva, Dissertation abstract, Moscow, 1955, p. 11.

\section{Authors of articles in Vol. III, No. 4}

LINDSEY A. J. HUGHES, Lecturer, Department of Russian Studies, University of Reading.

SHIRIN AKINER, Research student in Byelorussian Linguistics, School of Slavonic and East European Studies, University of London.

A. NADSON, Librarian of the Francis Skaryna Byelorussian Library, London. 